Article

\title{
Copolymers Based on Indole-6-Carboxylic Acid and 3,4-Ethylenedioxythiophene as Platinum Catalyst Support for Methanol Oxidation
}

\author{
Tzi-Yi Wu ${ }^{1}$, Chung-Wen Kuo ${ }^{2, *}$, Yu-Lun Chen ${ }^{2}$ and Jeng-Kuei Chang ${ }^{3}$
}

1 Department of Chemical Engineering and Materials Engineering, National Yunlin University of Science and Technology, Yunlin 64002, Taiwan; E-Mail: t0718z@gmail.com

2 Department of Chemical and Materials Engineering, National Kaohsiung University of Applied Sciences, Kaohsiung 80778, Taiwan; E-Mail: grace19890114@gmail.com

3 Institute of Materials Science and Engineering, National Central University, Taoyuan 32001, Taiwan; E-Mail: jkchang@ncu.edu.tw

* Author to whom correspondence should be addressed; E-Mail: welly@cc.kuas.edu.tw; Tel.: +886-7-3814526 (ext. 5138); Fax: +886-7-3830674.

Academic Editor: Minhua Shao

Received: 6 August 2015 / Accepted: 25 September 2015 / Published: 5 October 2015

\begin{abstract}
Indole-6-carboxylic acid (ICA) and 3,4-ethylenedioxythiophene (EDOT) are copolymerized electrochemically on a stainless steel (SS) electrode to obtain poly(indole-6-carboxylic acid-co-3,4-ethylenedioxythiophene)s (P(ICA-co-EDOT))s. The morphology of P(ICA-Co-EDOT)s is checked using scanning electron microscopy (SEM), and the SEM images reveal that these films are composed of highly porous fibers when the feed molar ratio of ICA/EDOT is greater than 3/2. Platinum particles can be electrochemically deposited into the P(ICA-co-EDOT)s and PICA films to obtain P(ICA-co-EDOT)s-Pt and PICA-Pt composite electrodes, respectively. These composite electrodes are further characterized using X-ray photoelectron spectroscopy (XPS), SEM, $\mathrm{X}$-ray diffraction analysis (XRD), and cyclic voltammetry (CV). The SEM result indicates that Pt particles disperse more uniformly into the highly porous $\mathrm{P}(\mathrm{ICA} 3-\mathrm{Co}$-EDOT2) fibers (feed molar ratio of ICA/EDOT = 3/2). The P(ICA3-Co-EDOT2)-Pt nanocomposite electrode exhibited excellent catalytic activity for the electrooxidation of methanol in these electrodes, which reveals that P(ICA3-Co-EDOT2)-Pt nanocomposite electrodes are more promising for application in an electrocatalyst as a support material.
\end{abstract}


Keywords: indole-6-carboxylic acid; 3,4-ethylenedioxythiophene; copolymer; methanol; electrocatalyst

\section{Introduction}

Electrochemical oxidation of methanol has been widely studied in the last decades due to their application for electrochemical energy conversion in direct methanol fuel cells (DMFC) [1-3]. The DMFC is considered a highly promising power source as an alternative to conventional energy converting devices due to its high power density, high energy-conversion efficiency, low emission of pollutants, and good fuel availability [4,5]. Despite the many efforts devoted to DMFC development, the usefulness of DMFCs is limited by the requirement of expensive platinum electrocatalyst for the methanol oxidation; platinum reserves on earth are limited, and the electrocatalytic efficiency is restricted by poisonous CO species on the Pt surface. These reasons limit the development and commercialization of DMFCs.

One of the practical solutions has been to decrease the use of pure platinum and enhance the catalytic efficiency of the entire catalyst (Pt and support) for methanol oxidation, such as with Pt-based bimetallic catalysts (Pt-Ru, Pt-Cu, Pt-Pd, Pt-WO, Pt-Co, Pt-Sn, Pt-Pb, Pt-Rh, and Pt-Au) [6-10]. Bimetallic catalysts are composed of two distinct metal elements, which significantly reduce the over-potential of methanol oxidation and offer considerable improvement in the catalytic properties relative to the individual metals. Moreover, the Pt-based bimetallic catalysts decrease the high Pt cost.

In recent years, conducting polymers (CPs) have been demonstrated to be suitable host materials for dispersing metallic particles [11-14]. CP matrices with porous structures, high accessible surface area, low chemical resistance and high stability are attractive and favorable supports for incorporation of the catalyst particles [15-17]. Moreover, this support structure avoids the agglomeration and reduces the Pt loading under the condition of keeping high catalytic activity.

Nowadays, the most common conducting polymers, such as polyaniline (PANI) [18], polypyrrole (PPy) [19], polythiophene (PTh) [20], polycarbazole [21], polyindole (PIn) [22], and their derivatives, have been successfully used as catalyst supports for methanol oxidation. Among many promising CPs, polypyrrole has the advantages of good electrical conductivity and ease of anodic electrodeposition of freestanding polypyrrole films. Indole has both a benzene ring and a pyrrole ring, the incorporation of a benzene unit link to the indole unit increases the chemical stability of polyindole. Poly(3,4-ethylenedioxythiophene) (PEDOT) is an important polythiophene derivative with two electron-donating oxygen atoms on 3,4-positions of thiophene PEDOT has good chemical and electrochemical properties in comparison with other kinds of polythiophene derivatives.

Copolymerization is an easy, facile method for preparing a specific polymer with different properties than those of their corresponding homopolymers. Synthesis of conjugated copolymer involves chemical and electrochemical polymerization [23,24]. Electrochemical copolymerization can be carried out at room temperature and homogeneous copolymer films can be formed directly at the electrode surface. During the past few years, copolymers have received increasing attention because they allow the preservation of homopolymers' properties and display specific electrochemical and 
physicochemical properties [25]. In the present work, poly(indole-6-carboxylic acid)-based homopolymers and copolymers are used as catalyst supports, and carboxylic acid groups are incorporated into the polymer backbone to help the uptake of $\mathrm{Pt}^{4+}$ ions and prevent the aggregation of Pt particles. P(ICA-Co-EDOT)s are prepared on the stainless steel (SS) electrode using the electrochemical copolymerization of indole-6-carboxylic acid (ICA) and EDOT, and the feed molar percentage of ICA/(ICA+EDOT) is $100,80,60$, and $40 \%$. The characteristics of deposited homopolymer and copolymer films are characterized by Fourier transform infrared spectroscopy (FT-IR) and scanning electron microscopy (SEM). Platinum particles were deposited onto the homopolymer and copolymer films using $\mathrm{H}_{2} \mathrm{PtCl}_{6}$ as the precursor to prepare PICA-Pt, P(ICA4-co-EDOT1)-Pt, $\mathrm{P}(\mathrm{ICA} 3-\mathrm{co}-\mathrm{EDOT} 2)-\mathrm{Pt}$, and $\mathrm{P}(\mathrm{ICA} 2-\mathrm{Co}$-EDOT3)-Pt composite catalyst supports, and their morphology and platinum particle size were investigated by SEM and X-ray diffraction (XRD), respectively. The electrochemical surface areas, electrocatalytic properties, and long-time stability toward methanol oxidation of the as-prepared composite catalyst were obtained by implementing cyclic voltammetry and chronoamperometry measurements in $0.5 \mathrm{M}$ methanol $+0.5 \mathrm{M} \mathrm{H}_{2} \mathrm{SO}_{4}$ solution. The present work focuses on the preparation of homopolymer and copolymer films using various feed molar percentages of ICA/EDOT and investigates the electrocatalytic activities of their Pt catalyst supports towards methanol oxidation.

\section{Results and Discussion}

\subsection{Electrochemical Polymerization and Characterizations}

The anodic polarization curves of $0.02 \mathrm{M}$ EDOT and $0.02 \mathrm{M}$ ICA in an acetonitrile (ACN) solution containing $0.1 \mathrm{M} \mathrm{LiClO}_{4}$ as the supporting electrolytes are shown in Figure 1. The onset oxidation potential ( $E_{\text {onset}}$ ) of EDOT and ICA in the solution is about +0.77 and $+0.83 \mathrm{~V}$ ( $v s$. $\mathrm{Ag} / \mathrm{AgCl})$, respectively.

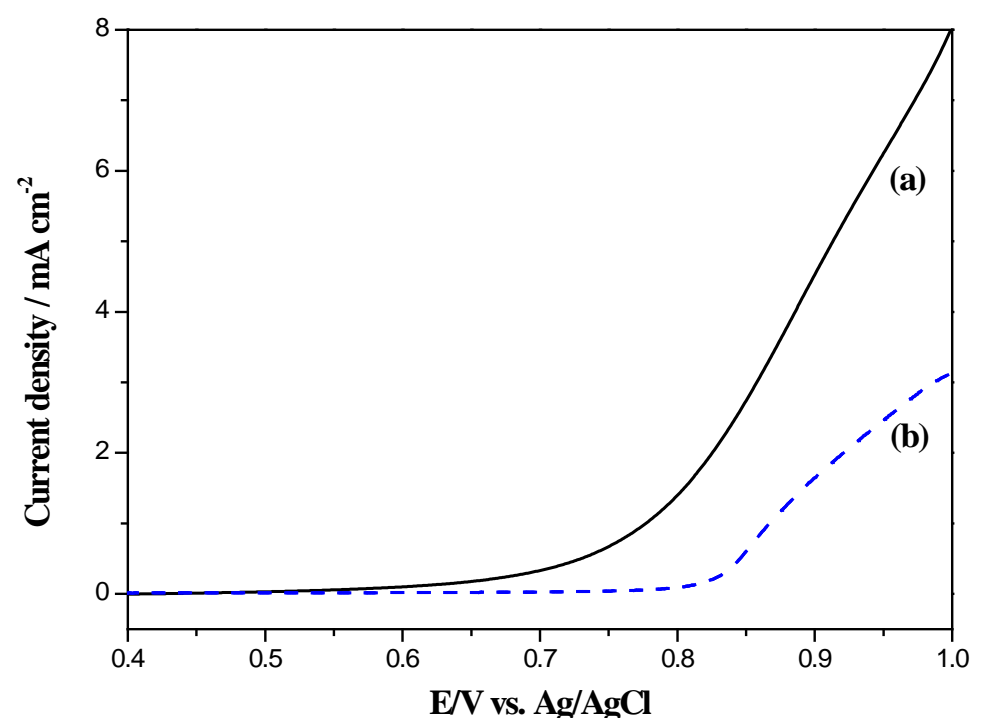

Figure 1. Anodic polarization curves of (a) $0.02 \mathrm{M}$ EDOT and (b) $0.02 \mathrm{M}$ ICA in $\mathrm{ACN}+0.1 \mathrm{M} \mathrm{LiClO}_{4}$. Scanning rates: $50 \mathrm{mV} \mathrm{s}^{-1}$. 
It is well known that successful electrochemical copolymerization of different monomers is due to the fact that the Eonset values of the monomers are close to each other [26]. The difference of the onset oxidation potential between EDOT and ICA monomers is $0.06 \mathrm{~V}$, implying that the electrochemical copolymerization may happen at the proper potential [27]. The schematic illustration for the formation of $\mathrm{P}(\mathrm{ICA}-\mathrm{co}-\mathrm{EDOT})$ is shown in Figure 2.
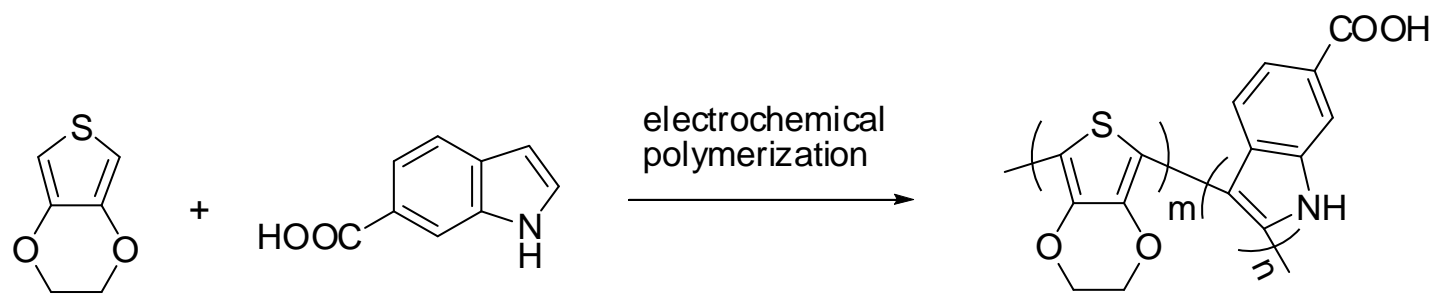

Figure 2. Schematic illustration for the formation of P(ICA-co-EDOT).

Figure 3a-d shows the FT-IR spectra of PICA, P(ICA4-co-EDOT1), P(ICA3-co-EDOT2), and $\mathrm{P}(\mathrm{ICA} 2-\mathrm{co}$-EDOT3) films. The PICA (curve a) exhibits some peaks, the $-\mathrm{C}-\mathrm{N}$ stretching vibration of PICA is observed clearly at $1295 \mathrm{~cm}^{-1}$, and the absorption peak at $1615 \mathrm{~cm}^{-1}$ is attributed to $\mathrm{C}=\mathrm{C}$ stretching. The characteristic $-\mathrm{C}=\mathrm{O}$ groups of PICA are observed at $1695 \mathrm{~cm}^{-1}$ [24]. These characteristic peaks of PICA can also be seen in copolymers (curve b-d). Compare with PICA homopolymer, the absorption peaks of the C-S bond in P(ICA4-co-EDOT1), P(ICA3-co-EDOT2), and $\mathrm{P}$ (ICA2-co-EDOT3) films can be observed at 860 and $698 \mathrm{~cm}^{-1}$ [28]. This implies that the 3,4-ethylenedioxythiophene units are incorporated into the copolymer chain. The absorption peaks of PICA are located at $1695 \mathrm{~cm}^{-1}$, whereas the absorption peaks of these copolymers shifted to short wavenumber position, indicating the formation of P(ICA4-co-EDOT1), P(ICA3-co-EDOT2), and $\mathrm{P}(\mathrm{ICA} 2-\mathrm{co}$-EDOT3) copolymers by the electrochemical polymerization. For instance, the characteristic peak shifts to $1680 \mathrm{~cm}^{-1}$ (curve d) when the feed molar ratio of ICA/EDOT is 2/3.

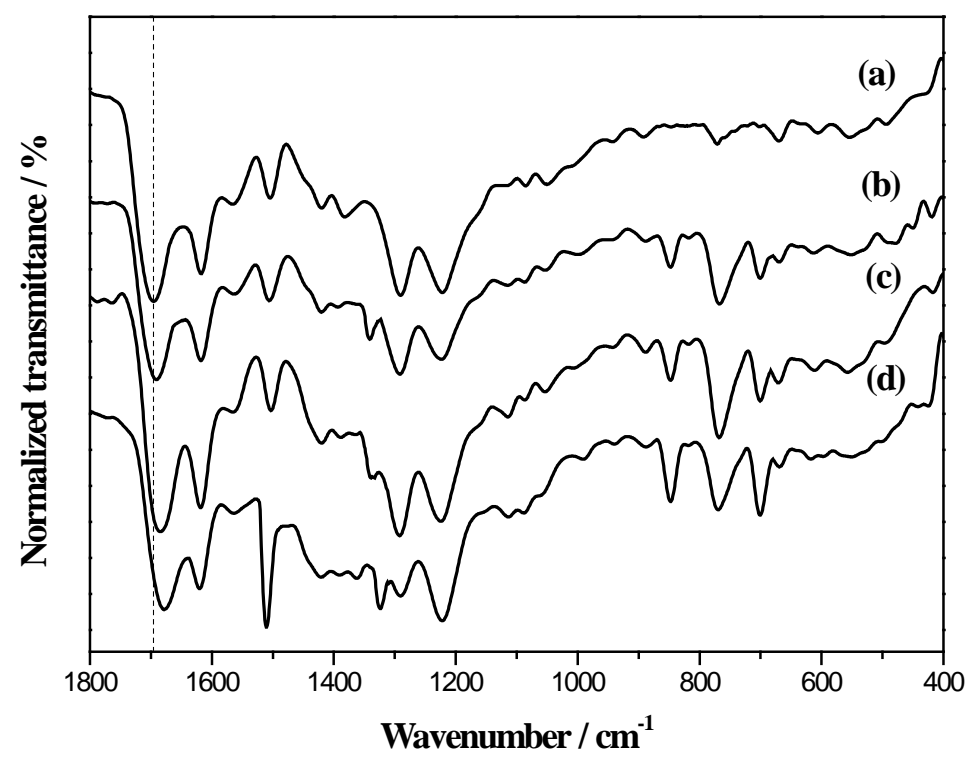

Figure 3. FT-IR spectra of (a) PICA; (b) P(ICA4-co-EDOT1); (c) P(ICA3-co-EDOT2); and (d) P(ICA2-co-EDOT3). 
XPS is a quantitative spectroscopic method for the element analysis. Figure 4a shows the survey scan of PICA-Pt, P(ICA4-co-EDOT1)-Pt, P(ICA3-co-EDOT2)-Pt, and P(ICA2-co-EDOT3)-Pt. Signals of $\mathrm{C}_{1 \mathrm{~s}}, \mathrm{~N}_{1 \mathrm{~s}}, \mathrm{O}_{1 \mathrm{~s}}, \mathrm{Pt}_{4 \mathrm{f}}$, and $\mathrm{S}_{2 \mathrm{p}}$ can be seen from Figure 4a. The Pt core-level spectra of E-Pt (Pt particles were deposited onto the stainless steel electrode), PICA-Pt, P(ICA4-co-EDOT1)-Pt, $\mathrm{P}\left(\mathrm{ICA} 3-\mathrm{co}-\mathrm{EDOT}\right.$ )-Pt, and P(ICA2-co-EDOT3)-Pt are shown in Figure 4b. The intensive $\mathrm{Pt}_{4 \mathrm{f}}$ binding energy peaks appeared at 71.3 and $74.7 \mathrm{eV}$ are metallic Pt [29]. The depositions of Pt particle on PICA, P(ICA4-co-EDOT1), P(ICA3-co-EDOT2), and P(ICA2-co-EDOT3) films influence the $\mathrm{N}_{1 \mathrm{~s}}$ orbital of polymers and $\mathrm{Pt}_{4 \mathrm{f}}$ orbital of $\mathrm{Pt}$, this could change the $\mathrm{Pt}_{4 \mathrm{f}}$ energy level for the PICA-Pt, P(ICA4-co-EDOT1)-Pt, P(ICA3-co-EDOT2)-Pt, and P(ICA2-co-EDOT3)-Pt electrodes. For instance, the $\mathrm{Pt}_{4 \mathrm{f}}$ peaks of E-Pt (71.3 and $74.7 \mathrm{eV}$ ) shifted to 70.5 and $73.9 \mathrm{eV}$ (P(ICA3-Co-EDOT2)-Pt (curve IV in Figure 4b), respectively.
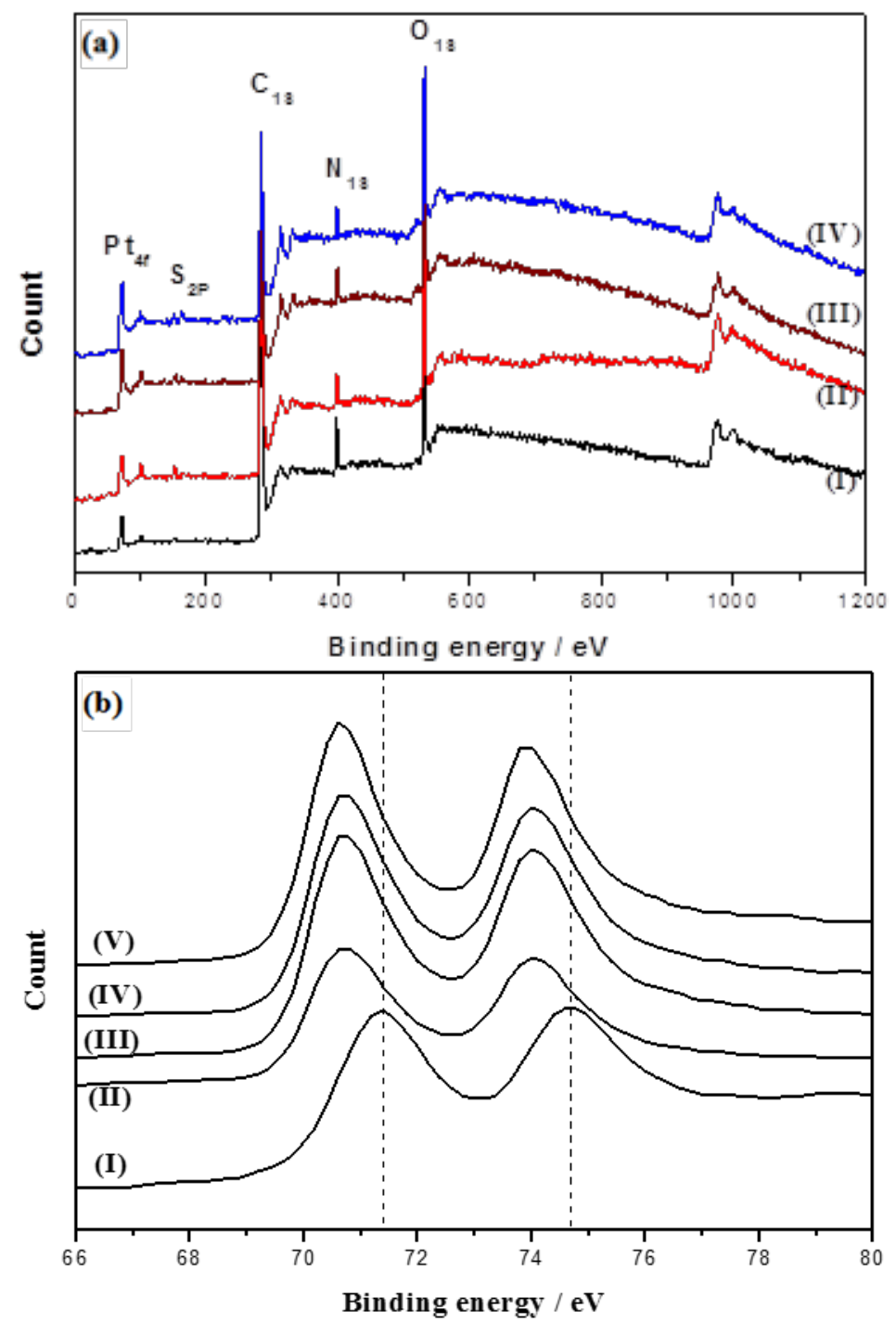

Figure 4. (a) XPS spectra of the survey scan (I) PICA-Pt, (II) P(ICA4-co-EDOT1)-Pt, (III) P(ICA3-co-EDOT2)-Pt, and (IV) P(ICA2-co-EDOT3)-Pt; (b) Pt 4 f XPS core-level spectra of (I) E-Pt, (II) PICA-Pt, (III) P(ICA4-co-EDOT1)-Pt, (IV) P(ICA3-co-EDOT2)-Pt, and (V) P(ICA2-co-EDOT3)-Pt. 


\subsection{Surface Morphology}

Figure 5a-h shows the scanning electron microscopy (SEM) analysis of surface morphology of PICA, PICA-Pt, P(ICA4-co-EDOT1), P(ICA4-co-EDOT1)-Pt, P(ICA3-co-EDOT2), P(ICA3-co-EDOT2)-Pt, P(ICA2-co-EDOT3), and P(ICA2-co-EDOT3)-Pt composite electrodes. The SEM images reveal that these films without Pt are composed of highly porous fibers when the feed molar ratio of ICA/EDOT is greater than 3/2, and the fibers have an average diameter of 50-200 nm.
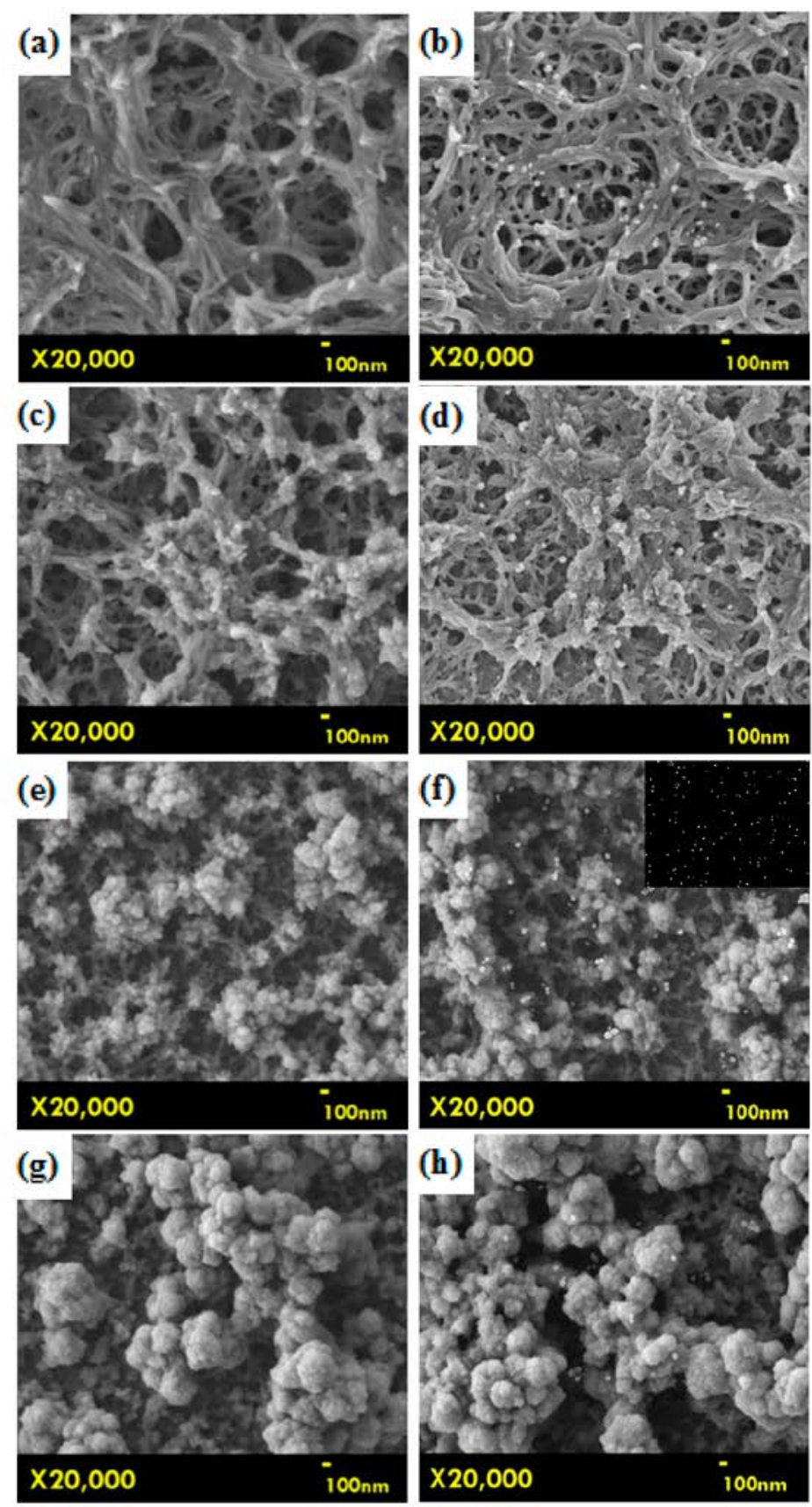

Figure 5. SEM images of (a) PICA; (b) PICA-Pt; (c) P(ICA4-co-EDOT1); (d) P(ICA4-co-EDOT1)-Pt; (e) P(ICA3-co-EDOT2); (f) P(ICA3-co-EDOT2)-Pt; (g) P(ICA2-co-EDOT3); and (h) P(ICA2-co-EDOT3)-Pt composite films; inset in (f) is $\mathrm{X}$-ray map (bright spots indicate $\mathrm{Pt}$ ). 
The fibers with cloud shape morphology of P(ICA3-co-EDOT2) film can be clearly seen in Figure 5e. However, P(ICA2-co-EDOT3) films show aggregative cloud shape morphology in Figure 5g, implying excess EDOT feed ratio gives rise to the formation of cloud shape structures. The fiber morphology of these films provides a large surface area for the subsequent deposition of Pt particles. Pt particles were incorporated into these films by electrochemical deposition at a constant potential of $-0.2 \mathrm{~V}$ (vs. Ag/AgCl).

As shown in Figure 5b,d,f,h, the incorporation of Pt into PICA, P(ICA4-co-EDOT1), $\mathrm{P}(\mathrm{ICA} 3-\mathrm{Co}-\mathrm{EDOT} 2), \mathrm{P}(\mathrm{ICA} 2-\mathrm{Co}-\mathrm{EDOT} 3)$ did not alter their morphologies. Pt particles can be clearly seen on these composite electrodes from SEM images. Pt particles with a size of about 30-100 nm can be seen on the PICA-Pt electrode, whereas Pt particles are about 30-60 nm on the $\mathrm{P}(\mathrm{ICA} 4-\mathrm{Co}-\mathrm{EDOT}$ )-Pt and P(ICA2-co-EDOT3)-Pt electrodes. The particle size of Pt (20-50 nm) for the $\mathrm{P}(\mathrm{ICA3}-\mathrm{Co}$-EDOT2)-Pt electrode is smaller than those for other three electrodes, which indicates that the P(ICA3-co-EDOT2)-Pt electrode presents a higher active surface area. The uniform distribution of $\mathrm{Pt}$ in the $\mathrm{P}(\mathrm{ICA} 3-\mathrm{Co}$-EDOT2) spatial network structure may increase the utilization of Pt for methanol oxidation. The inset in Figure $5 \mathrm{f}$ shows the result of $\mathrm{Pt}$ in a $\mathrm{P}(\mathrm{ICA3}-$-co-EDOT2)-Pt composite electrode. The bright spots indicate the existence of platinum in the electrode.

\subsection{XRD Patterns}

The crystalline structure of $\mathrm{Pt}$ particles incorporated into PICA, P(ICA4-co-EDOT1), $\mathrm{P}(\mathrm{ICA} 3-\mathrm{Co}-\mathrm{EDOT}$ ), and P(ICA2-co-EDOT3) composite electrodes are examined using XRD analysis, and the XRD patterns are displayed in Figure 6. These electrodes show intensive peaks at $2 \theta=43^{\circ}$ and $51^{\circ}$, indicating the diffraction peaks of the SS electrode. In addition, the characteristic diffraction peaks of face-centered cubic (fcc) platinum for the four electrodes are observed at $40^{\circ}, 46^{\circ}$, and $68^{\circ}$, corresponding to $\mathrm{Pt}(111), \operatorname{Pt}(200)$, and $\mathrm{Pt}(220)$ planes, respectively [8]. Because the $\mathrm{Pt}(111)$ peak is isolated with the diffraction peaks of PICA, P(ICA4-co-EDOT1), P(ICA3-co-EDOT2), and $\mathrm{P}(\mathrm{ICA} 2-\mathrm{Co}$-EDOT3) composite electrodes, the average size of Pt particles can be calculated from this peak according to Scherrer's formula, [30].

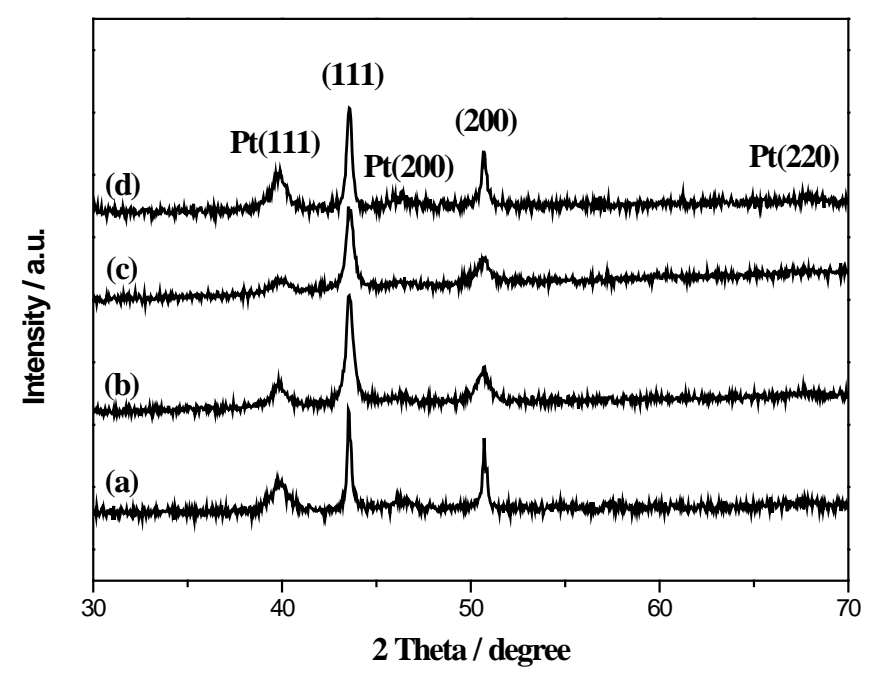

Figure 6. XRD patterns of (a) PICA-Pt; (b) P(ICA4-co-EDOT1)-Pt; (c) P(ICA3-co-EDOT2)-Pt; and (d) P(ICA2-co-EDOT3)-Pt. 


$$
d=\frac{0.9 \lambda}{\beta \cos \theta}
$$

where $d$ is the average size of the Pt particles, $\lambda$ is the X-ray wavelength ( $\mathrm{Cu} K \alpha \lambda=1.54178 \AA$ ), $\theta_{\max }$ is the diffraction angle at the peak position, and $\beta$ is the half-peak width for $\operatorname{Pt}(111)$ in radians. The average sizes of Pt particles for PICA-Pt, P(ICA4-co-EDOT1)-Pt, P(ICA3-co-EDOT2)-Pt, and $\mathrm{P}(\mathrm{ICA} 2-\mathrm{co}$-EDOT3)-Pt calculated using the Scherrer's equation were 10, 8, 8, and $9 \mathrm{~nm}$, respectively. The calculated size of Pt particles from Scherrer equation is smaller than the average diameter measured by SEM, which can be attributed to the fact that the particle size estimated from XRD and the Scherrer equation is the primary particle size. However, the particle size observed from SEM results is the secondary particle size (or aggregated particle size).

\subsection{Electrocatalytic Activity of Electrodes for Methanol Oxidation}

Figure 7a-d show the incorporation of Pt particles into in $\mathrm{P}(\mathrm{Id} 3-\mathrm{co}-\mathrm{Ed} 2)$ films via electrochemical deposition at a constant potential of $-0.2 \mathrm{~V}$ from $0.5 \mathrm{M} \mathrm{CH} 3 \mathrm{OH}+0.5 \mathrm{M} \mathrm{H}_{2} \mathrm{SO}_{4}$ solution with various deposition charges of $0.15,0.20,0.25$, and $0.30 \mathrm{C}$. The maximum anodic peak current density $\left(I_{\mathrm{pa}}\right)$ for the oxidation of methanol observed at the P(ICA3-co-EDOT2) electrode (deposition charge of $0.20 \mathrm{C}$ ) is $58 \mathrm{~mA} \cdot \mathrm{cm}^{-2} \cdot \mathrm{mg}^{-1}$, which is higher than those of other electrodes (deposition charges of $0.15,0.25$, and $0.30 \mathrm{C}$ ).

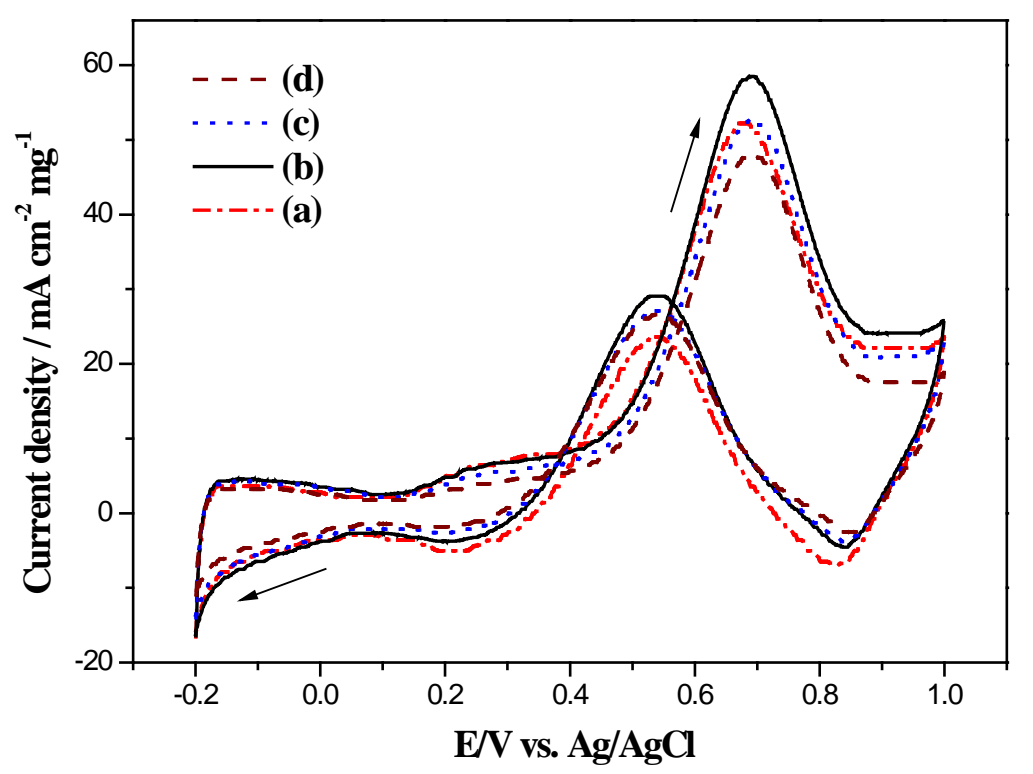

Figure 7. Cyclic voltammograms of $\mathrm{P}(\mathrm{ICA} 3-\mathrm{co}-\mathrm{EDOT2})$ with various $\mathrm{Pt}$ deposition charges of (a) 0.15; (b) 0.20; (c) 0.25; and (d) $0.30 \mathrm{C}$ in $0.5 \mathrm{M} \mathrm{CH}_{3} \mathrm{OH}+0.5 \mathrm{M} \mathrm{H}_{2} \mathrm{SO}_{4}$ solution, scan rate $=50 \mathrm{mV} \cdot \mathrm{s}^{-1}$.

Cyclic voltammograms (CVs) of PICA-Pt, P(ICA4-Co-EDOT1)-Pt, P(ICA3-co-EDOT2)-Pt, and $\mathrm{P}(\mathrm{ICA} 2-\mathrm{co}$-EDOT3)-Pt electrodes under the same Pt deposition charge of $0.20 \mathrm{C}$ recorded with a scan rate of $50 \mathrm{mV} \cdot \mathrm{s}^{-1}$ in $0.5 \mathrm{M} \mathrm{H}_{2} \mathrm{SO}_{4}$ are presented in Figure 8. These composite electrodes show obvious hydrogen adsorption/desorption differences in the range of 0.1 to $-0.2 \mathrm{~V}$. It is known that the integrated area represents the number of Pt sites available for hydrogen adsorption and desorption. 
Among these composite electrodes, P(ICA3-co-EDOT2)-Pt film shows the largest charge for hydrogen adsorption and desorption, and this may be ascribed to the uniform dispersion of Pt particles in $\mathrm{P}(\mathrm{ICA3}-\mathrm{co}$-EDOT2) spatial network structure. For example, the charge for hydrogen absorption and desorption on the $\mathrm{P}\left(\mathrm{ICA} 3-\mathrm{Co}\right.$-EDOT2)-Pt film is $71.4 \mathrm{mC} \cdot \mathrm{cm}^{-2} \cdot \mathrm{mg}^{-1}$, which is 1.5 times larger than that on the PICA-Pt surface $\left(48.9 \mathrm{mC} \cdot \mathrm{cm}^{-2} \cdot \mathrm{mg}^{-1}\right)$. The electrochemical surface area (ESA) of Pt can be calculated from the area of hydrogen adsorption-desorption peaks using the following equation [31],

$$
E S A=\frac{Q_{\mathrm{H}}}{0.21[\mathrm{Pt}]}
$$

where $Q_{\mathrm{H}}\left(\mathrm{mC} \cdot \mathrm{cm}^{-2}\right)$ represents the mean value between the amounts of charge exchanged during the electro-adsorption $\left(Q_{1}\right)$ and desorption $\left(Q_{2}\right)$ of $\mathrm{H}_{2}$ on Pt sites, $[\mathrm{Pt}]$ is the Pt loading $\left(\mathrm{mg} \cdot \mathrm{cm}^{-2}\right)$ on the electrode, and $0.21\left(\mathrm{mC} \cdot \mathrm{cm}^{-2}\right)$ represents the charge required to oxidize a monolayer of $\mathrm{H}_{2}$ on clean Pt. The contribution from the double layer capacitance is deduced while calculating the ESA. As shown in Table 1, the ESA values of Pt supported on the PICA-Pt, P(ICA4-co-EDOT1)-Pt, $\mathrm{P}(\mathrm{ICA} 3-\mathrm{Co}-\mathrm{EDOT} 2)-\mathrm{Pt}$, and P(ICA2-co-EDOT3)-Pt electrodes are calculated to be 230, 286, 340, and $283 \mathrm{~cm}^{2} \cdot \mathrm{mg}^{-1}$, respectively.

Table 1. The ESA values of Pt supported on the electrodes.

\begin{tabular}{|c|c|c|}
\hline Electrodes & $Q_{H}\left(\mathrm{mC} \mathrm{cm}^{-2} \cdot \mathrm{mg}^{-1}\right)$ & $\operatorname{ESA}\left(\mathrm{cm}^{2} \cdot \mathrm{mg}^{-1}\right)$ \\
\hline PICA-Pt & 48.9 & 230 \\
\hline P(ICA4-co-EDOT1)-Pt & 60.1 & 286 \\
\hline P(ICA3-co-EDOT2)-Pt & 71.4 & 340 \\
\hline P(ICA2-co-EDOT3)-Pt & 60.0 & 283 \\
\hline
\end{tabular}

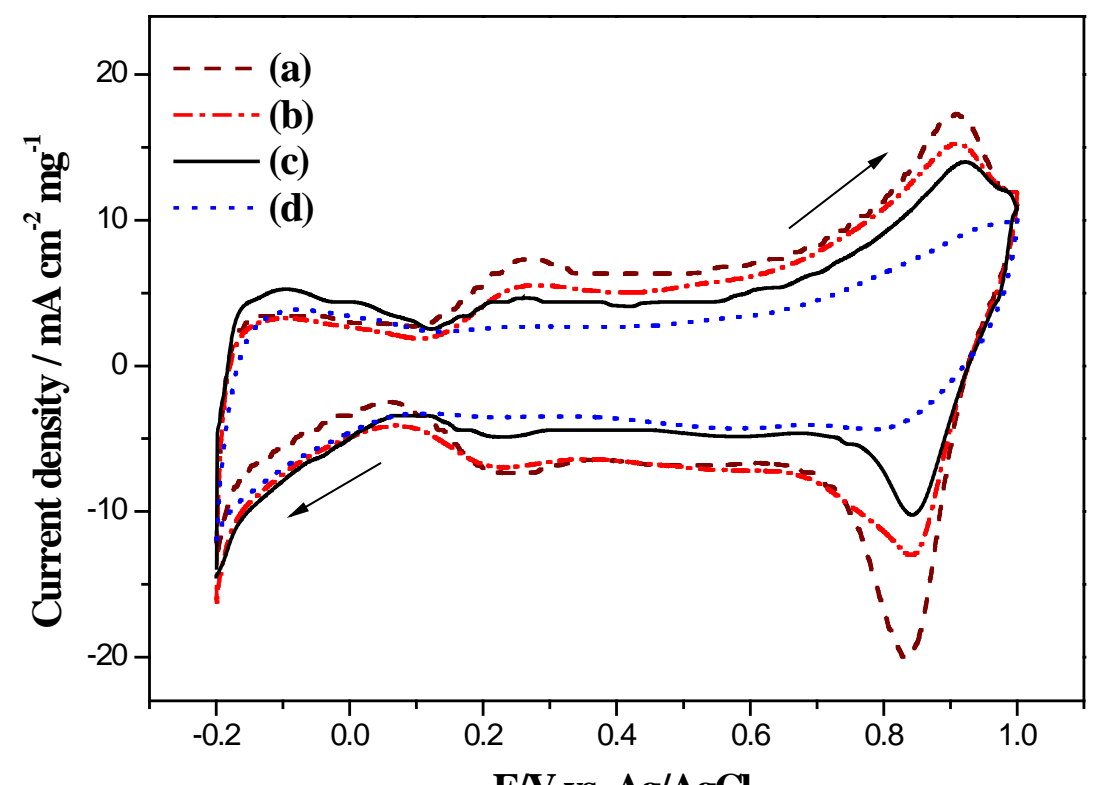

E/V vs. Ag/AgCl

Figure 8. Cyclic voltammograms of (a) PICA-Pt; (b) P(ICA4-co-EDOT1)-Pt; (c) $\mathrm{P}$ (ICA3-Co-EDOT2)-Pt; and (d) $\mathrm{P}(\mathrm{ICA} 2-\mathrm{Co}-\mathrm{EDOT} 3)-\mathrm{Pt}$ in $0.5 \mathrm{M} \mathrm{H}_{2} \mathrm{SO}_{4}$ solution, the deposition charge of Pt is $0.20 \mathrm{C}$, scan rate $=50 \mathrm{mV} \cdot \mathrm{s}^{-1}$. 
The Pt particles are loaded onto PICA, P(ICA4-co-EDOT1), P(ICA3-co-EDOT2), P(ICA2-co-EDOT3)-Pt, and PEDOT-Pt composite electrodes under the same Pt deposition charge of $0.20 \mathrm{C}$ and tested for their electrocatalytic activity of methanol oxidation by cyclic voltammetry. As shown in Figure 9, the current for the methanol oxidation increases slowly below $0.5 \mathrm{~V}$ in the forward sweep for these electrodes, which can be ascribed to the formation of reaction intermediates. The current increases quickly and reaches a peak at around $0.7 \mathrm{~V}$, and this can be attributed to the partial oxidation of Pt surface, which helps the transformation of intermediates to carbon dioxide.

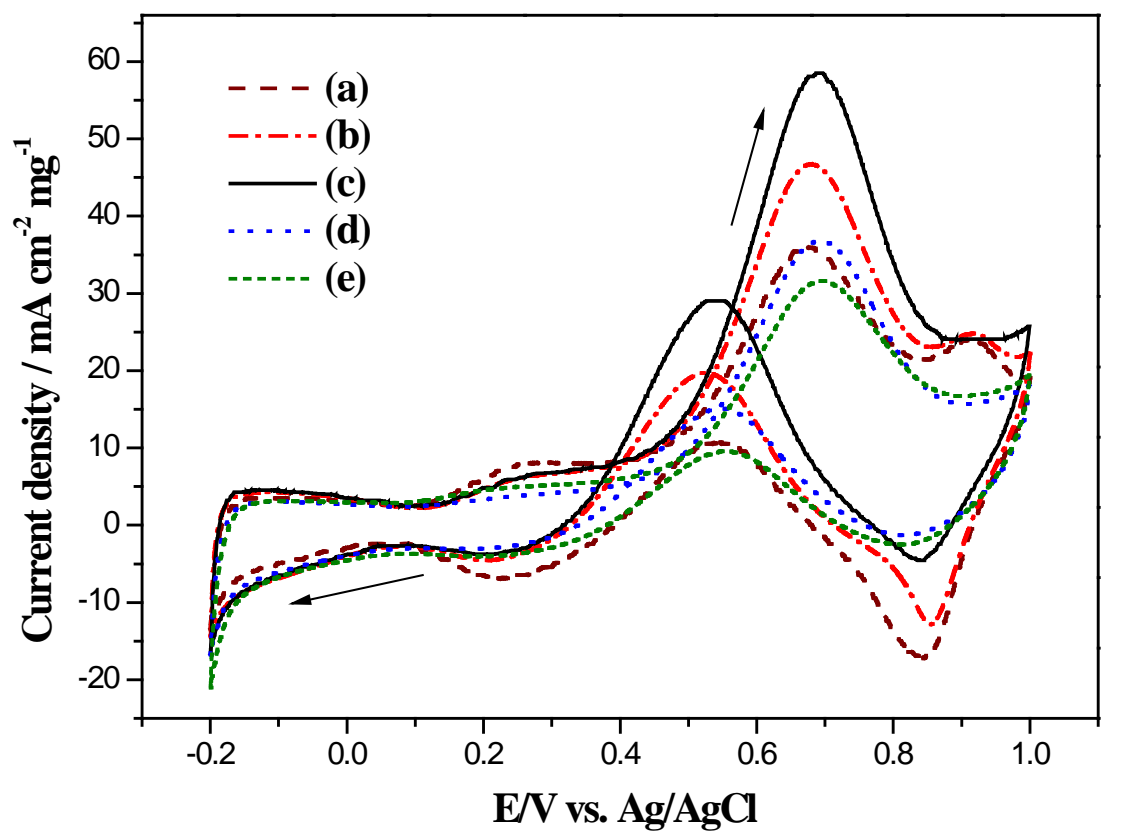

Figure 9. Cyclic voltammograms of (a) PICA-Pt; (b) P(ICA4-co-EDOT1)-Pt; (c) P(ICA3-co-EDOT2)-Pt; (d) P(ICA2-co-EDOT3)-Pt; and (e) PEDOT-Pt in $0.5 \mathrm{M}$ $\mathrm{CH}_{3} \mathrm{OH}+0.5 \mathrm{M} \mathrm{H} \mathrm{H}_{2} \mathrm{SO}_{4}$ solution; the deposition charge of $\mathrm{Pt}$ is $0.20 \mathrm{C}$, scan rate $=50 \mathrm{mV} \cdot \mathrm{s}^{-1}$.

The anodic peak current density for the methanol oxidation of PICA-Pt and P(ICA2-co-EDOT3)-Pt electrodes (curve a and d) is about $36 \mathrm{~mA} \cdot \mathrm{cm}^{-2} \cdot \mathrm{mg}^{-1}$, which is lower than P(ICA4-co-EDOT1)-Pt and $\mathrm{P}(\mathrm{ICA} 3-\mathrm{co}$-EDOT2)-Pt electrodes. Comparing the $\mathrm{CV}$ results of these electrodes, the highest oxidation current $\left(I_{\mathrm{pa}}\right)$ toward methanol oxidation is observed for the P(ICA3-co-EDOT2)-Pt electrode, confirming the crucial effect of P(ICA3-co-EDOT2)-Pt on the enhancement of platinum particle efficiency towards the catalytic oxidation of methanol. The highest current density for the $\mathrm{P}(\mathrm{ICA} 3-\mathrm{Co}-\mathrm{EDOT} 2)-\mathrm{Pt}$ electrode may be due to suitable amounts of $\mathrm{CO}_{2}{ }^{-}$groups helping with the uptake of $\mathrm{Pt}^{4+}$ ions. A uniform distribution of Pt particles into P(ICA3-co-EDOT2) can twist to form a spatial 3D matrix. As shown in Table 2, the methanol oxidation on P(ICA3-co-EDOT2)-Pt electrode shows higher current density $\left(I_{\mathrm{pa}}\right)$ than those reported for PANI-300PSS-Pt [32], Pt/PANI/MGCE [33], Pt/Nano-PDAN/MGCE [34], and PANI-PSS-Pt [11]. However, P(ICA3-co-EDOT2)-Pt electrode shows lower $I_{p a}$ than that reported for nanotube-Pt [35]. 
Table 2. Comparisons of the methanol oxidation data in $\mathrm{H}_{2} \mathrm{SO}_{4}$ solution at the P(ICA3-co-EDOT2)-Pt composite electrode with some modified electrodes.

\begin{tabular}{|c|c|c|c|c|c|}
\hline Electrodes & $\begin{array}{c}\mathrm{C}_{\mathrm{H} 2 \mathrm{SO} 4} / \mathrm{C}_{\text {Methanol }} \\
(\mathrm{M} / \mathrm{M})\end{array}$ & $\begin{array}{c}v \\
\left(m V \cdot s^{-1}\right)\end{array}$ & $\begin{array}{l}E_{\text {onset }} \\
(\mathrm{V})^{(\mathrm{c})}\end{array}$ & $\begin{array}{c}I_{\mathbf{p a}} \\
\left(\mathbf{m A} \cdot \mathbf{m g}^{-1}\right)\end{array}$ & Ref. \\
\hline PANI-300PSS-Pt ${ }^{(\mathrm{b})}$ & $0.5 / 0.1$ & 10 & 0.4 & 19 & [32] \\
\hline Pt/PANI/MGCE ${ }^{\text {(a) }}$ & $0.5 / 0.5$ & 5 & 0.3 & 32 & [33] \\
\hline Pt/Nano-PDAN/MGCE ${ }^{\text {(a) }}$ & $0.5 / 2.4$ & 50 & 0.2 & 28 & [34] \\
\hline PANI-PSS-Pt ${ }^{(\mathrm{b})}$ & $0.5 / 1.0$ & 10 & 0.4 & 31 & {$[11]$} \\
\hline nanotube-Pt $^{(\mathrm{b})}$ & $0.5 / 1.0$ & 50 & - & 141 & [35] \\
\hline P(ICA3-co-EDOT2)-Pt ${ }^{(\mathrm{b})}$ & $0.5 / 0.5$ & 50 & 0.4 & 58 & This work \\
\hline
\end{tabular}

(a) The potentials were referred to SCE; (b) The potentials were referred to $\mathrm{Ag} / \mathrm{AgCl}$; (c) The methanol oxidation onset potential.

The effect of methanol concentration on the electrocatalytic activity of these composite electrodes is examined (Figure 10). It can be clearly observed that the anodic current increases with increasing methanol concentration and levels off at concentrations higher than $1.5 \mathrm{M}$. This effect can be attributed to the saturation of active sites at the surface of the electrode, and the optimum concentration of methanol for a higher current density may be considered to be about $1.5 \mathrm{M}$.

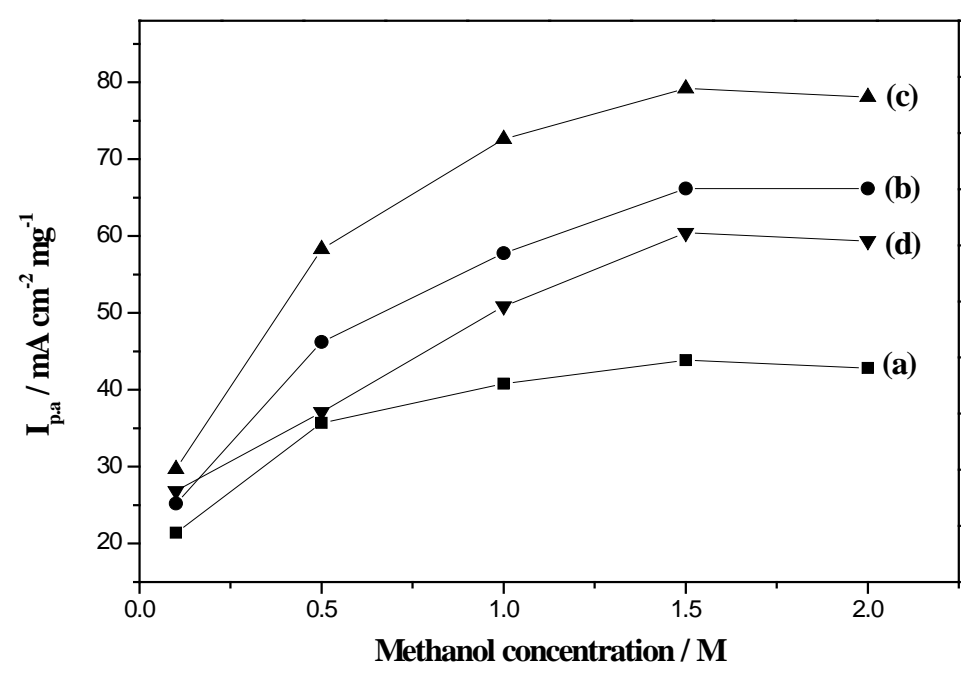

Figure 10. Plot of anodic peak current as a methanol concentration for (a) PICA-Pt; (b) P(ICA4-co-EDOT1)-Pt; (c) P(ICA3-co-EDOT2)-Pt; and (d) P(ICA2-co-EDOT3)-Pt. Supporting electrolyte: $0.5 \mathrm{M} \mathrm{H}_{2} \mathrm{SO}_{4}$. Scan rate: $50 \mathrm{mV} \cdot \mathrm{s}^{-1}$.

\subsection{Electrocatalytic Long-Term Stability of Electrodes for Methanol Oxidation}

The performance of four electrodes towards the methanol oxidation reaction after long term operation was tested using chronoamperometry. Figure 11 shows the current-time responses of PICA-Pt, P(ICA4-co-EDOT1)-Pt, P(ICA3-co-EDOT2)-Pt, and P(ICA2-co-EDOT3)-Pt electrodes recorded at $0.6 \mathrm{~V}$ in $0.5 \mathrm{M} \mathrm{CH}_{3} \mathrm{OH}+0.5 \mathrm{M} \mathrm{H}_{2} \mathrm{SO}_{4}$ solution for $5 \mathrm{~h}$. After long term operation, a steady state current density is achieved. It can also be observed that the electrocatalyst of $\mathrm{P}(\mathrm{ICA} 3-\mathrm{co}-\mathrm{EDOT2})-\mathrm{Pt}$ maintained the highest current density in these electrodes. The methanol oxidation currents at $3 \mathrm{~h}$ follow this order: P(ICA3-co-EDOT2)-Pt $\left(6.8 \mathrm{~mA} \cdot \mathrm{cm}^{-2} \cdot \mathrm{mg}^{-1}\right)>$ 
$\mathrm{P}\left(\mathrm{ICA} 4-\mathrm{co}\right.$-EDOT1)-Pt $\left(4.8 \mathrm{~mA} \cdot \mathrm{cm}^{-2} \cdot \mathrm{mg}^{-1}\right)>\mathrm{P}\left(\mathrm{ICA} 2-\mathrm{co}\right.$-EDOT3)-Pt $\left(3.2 \mathrm{~mA} \cdot \mathrm{cm}^{-2} \cdot \mathrm{mg}^{-1}\right)>\mathrm{PICA}-\mathrm{Pt}$ $\left(2.6 \mathrm{~mA} \cdot \mathrm{cm}^{-2} \cdot \mathrm{mg}^{-1}\right)$.

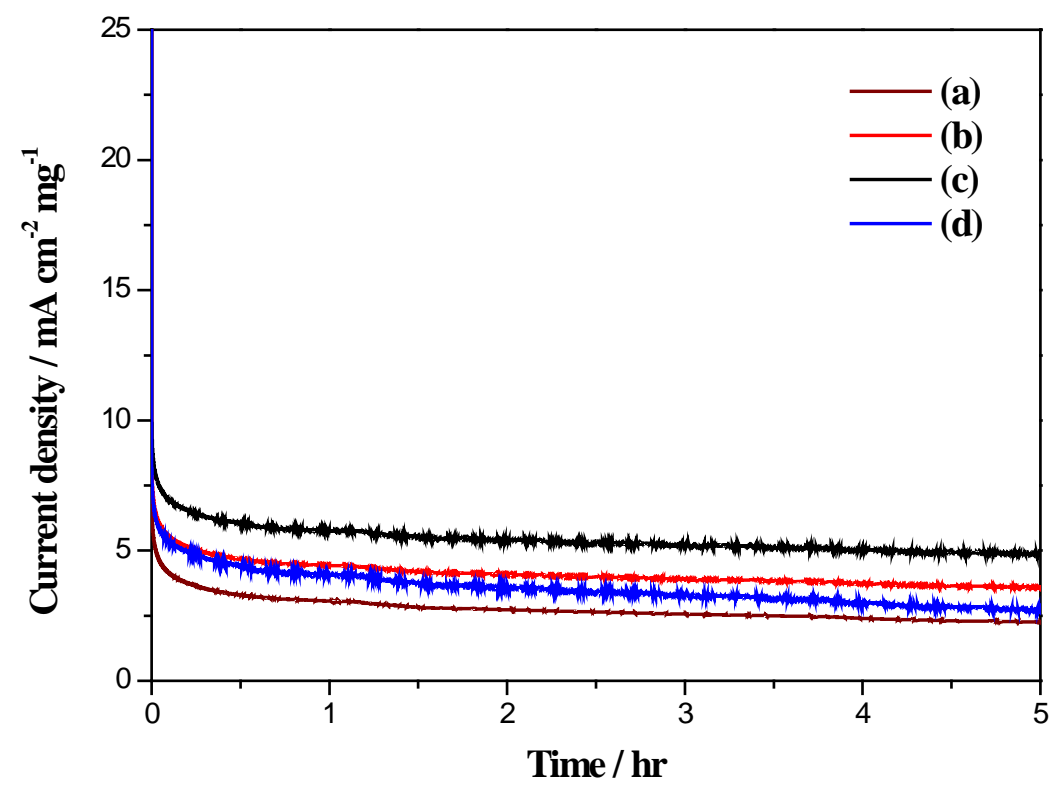

Figure 11. Chronoamperometric responses of (a) PICA-Pt; (b) P(ICA4-co-EDOT1)-Pt; (c) $\mathrm{P}(\mathrm{ICA} 3-$-co-EDOT2)-Pt; and (d) $\mathrm{P}(\mathrm{ICA} 2-c o-E D O T 3)-\mathrm{Pt}$ at $0.6 \mathrm{~V}$ (vs. Ag/AgCl) in $0.5 \mathrm{M} \mathrm{CH}_{3} \mathrm{OH}+0.5 \mathrm{M} \mathrm{H}_{2} \mathrm{SO}_{4}$ solution.

\section{Experimental Section}

\subsection{Preparation of PICA, P(ICA4-Co-EDOT1), P(ICA3-Co-EDOT2), and P(ICA2-Co-EDOT3) Films}

Before electrochemical studies, stainless steel (SS) substrates were cleaned in an ultrasonic bath using detergent, isopropanol, and deionized water, and all solutions were degassed with $\mathrm{N}_{2}$. The PICA, $\mathrm{P}(\mathrm{ICA} 4-$-co-EDOT1), $\mathrm{P}(\mathrm{ICA} 3-\mathrm{co}-\mathrm{EDOT} 2)$, and $\mathrm{P}(\mathrm{ICA} 2-$-co-EDOT3) films were deposited from a $20 \mathrm{mM}$ ICA, $16 \mathrm{mM}$ ICA + $4 \mathrm{mM}$ EDOT, $12 \mathrm{mM}$ ICA + $8 \mathrm{mM}$ EDOT, and $8 \mathrm{mM}$ ICA + $12 \mathrm{mM}$ EDOT in a $0.1 \mathrm{M} \mathrm{LiClO}_{4} / \mathrm{ACN}$ solution, respectively. Electrochemical deposition was carried out potentiostatically at $1.4 \mathrm{~V}$ (vs. Ag/AgCl electrode) for $0.08 \mathrm{C} \cdot \mathrm{cm}^{-2}$.

\subsection{Deposition of Pt into PICA, P(ICA4-co-EDOT1), P(ICA3-co-EDOT2), and} P(ICA2-co-EDOT3) Matrices

Pt particles were incorporated into PICA, P(ICA4-Co-EDOT1), P(ICA3-co-EDOT2), and $\mathrm{P}(\mathrm{ICA} 2-\mathrm{co}-\mathrm{EDOT} 3)$ polymer films via electrochemical deposition from $5 \mathrm{mM} \mathrm{H}_{2} \mathrm{PtCl}_{6}$ containing $0.5 \mathrm{M} \mathrm{H}_{2} \mathrm{SO}_{4}$ solution with a constant deposition charge of $0.20 \mathrm{C}$ at $-0.2 \mathrm{~V}$ (vs. Ag/AgCl). After the incorporation of $\mathrm{Pt}$ particles, the composite electrodes were washed with deionized water for 5 min and then dried at $120{ }^{\circ} \mathrm{C}$ for $3 \mathrm{~min}$. The weights of Pt loaded into PICA, P(ICA4-Co-EDOT1), $\mathrm{P}(\mathrm{ICA} 3-\mathrm{Co}-\mathrm{EDOT} 2), \mathrm{P}(\mathrm{ICA} 2-\mathrm{Co}-\mathrm{EDOT} 3)$, and PEDOT films are calculated using the TGA, and they are $125,115,128,118$, and $121 \mu \mathrm{g} \cdot \mathrm{cm}^{-2}$, respectively. The Pt wt. \% in PICA-Pt, P(ICA4-co-EDOT1)-Pt, 
P(ICA3-co-EDOT2)-Pt, P(ICA2-co-EDOT3)-Pt, and PEDOT-Pt catalysts are 32.8, 33.6, 34.8, 34.1, and $30.6 \%$, respectively.

\subsection{Physical and Electrochemical Characterizations}

The FT-IR spectra of PICA, P(ICA4-co-EDOT1), P(ICA3-co-EDOT2), and P(ICA2-Co-EDOT3) in $\mathrm{KBr}$ pellets were measured using a Perkin Elmer infrared spectrophotometer (Perkin Elmer, Waltham, MA, USA) with 16 scans at a resolution of $4 \mathrm{~cm}^{-1}$ and in the range of $400-4000 \mathrm{~cm}^{-1}$. An XPS study was carried out using an ESCA 210 spectrometer (VG Scientific, Waltham, MA, USA) with Mg Ka ( $h v=1253.6 \mathrm{eV}$ ) irradiation as the light source. The primary tension and the pressure were $12 \mathrm{kV}$ and ca. $10^{-10}$ mbar, respectively. The surface morphologies of as-prepared electrodes were studied using a scanning electron microscope (SEM) (JEOL, Boston, MA, USA) equipped with an energy-dispersive X-ray spectroscopy (EDS) detector (JEOL, Boston, MA, USA). X-ray diffraction spectra (XRD) for the as-prepared electrodes were obtained by exposing the samples to a Bruker D8 Discover (Bruker, Billerica, MA, USA) SSS X-ray source with $\mathrm{Cu} \mathrm{K} \alpha(\lambda=0.154 \mathrm{~nm})$ as a target, at diffraction angles $(2 \theta)$ ranging from $5^{\circ}$ to $90^{\circ}$ with a scan rate of $4^{\circ} \mathrm{min}^{-1}$.

Electrochemical characterizations of PICA-Pt, P(ICA4-co-EDOT1)-Pt, P(ICA3-co-EDOT2)-Pt, and P(ICA2-co-EDOT3)-Pt composite electrodes were implemented using a CHI627D electrochemical analyzer (Antec Leyden BV, Zoeterwoude, Netherlands). All experiments were carried out in a three-constituent cell. A Pt wire, SS (area $=1 \mathrm{~cm}^{2}$ ), and $\mathrm{Ag} / \mathrm{AgCl}$ electrode (in $3 \mathrm{M} \mathrm{KCl}$ ) were used as the counter, working and reference electrodes, respectively.

\subsection{Methanol Electro-Oxidation and Stability of Composite Electrodes}

The catalytic activities of composite electrodes were examined by $\mathrm{CV}$ at $50 \mathrm{mV} \cdot \mathrm{s}^{-1}$ in the range of -0.2 to $1.0 \mathrm{~V}$. Chronoamperometric response curves were obtained at $0.6 \mathrm{~V}$ in $0.5 \mathrm{M} \mathrm{CH} 3 \mathrm{OH}+0.5 \mathrm{M}$ $\mathrm{H}_{2} \mathrm{SO}_{4}$ solution. All the electrochemical experiments were carried out at room temperature.

\section{Conclusions}

Copolymers based on ICA and EDOT were successfully synthesized by electrochemical oxidation with various feed molar ratios of ICA/EDOT in ACN solution containing $0.1 \mathrm{M} \mathrm{LiClO}_{4}$. The existence of $-\mathrm{CO}_{2}{ }^{-}$groups in $\mathrm{P}(\mathrm{ICA} 3-\mathrm{Co}-\mathrm{EDOT} 2)$ spatial structure assists in holding $\mathrm{Pt}^{4+}$ ions in the polymer matrix, resulting in the homogenous distribution of Pt in P(ICA3-Co-EDOT2). Among the as-prepared catalysts, the $\mathrm{P}(\mathrm{ICA} 3-\mathrm{Co}-\mathrm{EDOT}$ )-Pt electrode exhibits the highest current density and the best stability toward methanol oxidation, demonstrating that the P(ICA3-co-EDOT2)-Pt composite electrode is a promising material as a catalyst for methanol oxidation.

\section{Acknowledgments}

The authors would like to thank the Ministry of Science and Technology of Republic of China for financially supporting this project under grants MOST 103-2221-E-151-051 and MOST 103-2221-E-224-058-MY3. 


\section{Author Contributions}

C.-W.K. and T.-Y.W. conceived and designed the experiments; Y.-L.C. performed the experiments; C.-W.K. and J.-K.C. analyzed the data; T.-Y.W. wrote the paper.

\section{Conflicts of Interest}

The authors declare no conflict of interest.

\section{References}

1. Alegre, C.; Gálvez, M.E.; Moliner, R.; Lázaro, M.J. Influence of the synthesis method for Pt catalysts supported on highly mesoporous carbon xerogel and vulcan carbon black on the electro-oxidation of methanol. Catalysts 2015, 5, 392-405.

2. Chen, X.; Wang, H.; Wang, Y.; Bai, Q.; Gao, Y.; Zhang, Z. Synthesis and electrocatalytic performance of multi-component nanoporous PtRuCuW alloy for direct methanol fuel cells. Catalysts 2015, 5, 1003-1015.

3. Wu, T.Y.; Chen, B.K.; Chang, J.K.; Chen, P.R.; Kuo, C.W. Nanostructured poly(aniline-co-metanilic acid) as platinum catalyst support for electro-oxidation of methanol. Int. J. Hydrogen Energy 2015, 40, 2631-2640.

4. Zhao, Y.L.; Wang, Y.H.; Zang, J.B.; Lu, J.; Xu, X.P. A novel support of nano titania modified graphitized nanodiamond for $\mathrm{Pt}$ electrocatalyst in direct methanol fuel cell. Int. J. Hydrogen Energy 2015, 40, 4540-4547.

5. Kamarudina, S.K.; Achmada, F.; Daud, W.R.W. Overview on the application of direct methanol fuel cell (DMFC) for portable electronic devices. Int. J. Hydrogen Energy 2010, 34, 6902-6916.

6. Chou, H.Y.; Yeh, T.K.; Tsai, C.H. Electrodeposited Pt and PtRu Nanoparticles without hydrogen evolution reaction on mesoporous carbon for methanol oxidation. Int. J. Electrochem. Sci. 2014, 9, 5763-5775.

7. Shen, P.K.; Tseung, A.C.C. Anodic oxidation of methanol on $\mathrm{Pt} / \mathrm{WO}_{3}$ in acidic media. J. Electrochem. Soc. 1994, 141, 3082-3090.

8. Wu, T.Y.; Kuo, Z.Y.; Jow, J.J.; Kuo, C.W.; Tsai, C.J.; Chen, P.R.; Chen, H.R. Co-electrodeposition of platinum and rhodium in poly(3,4-ethylenedioxythiophene)-poly(styrene sulfonic acid) as electrocatalyst for methanol oxidation. Int. J. Electrochem. Sci. 2012, 7, 8076-8090.

9. Caballero-Manrique, G.; Brillas, E.; Centellas, F.; Garrido, J.A.; Rodríguez, R.M.; Cabot, P.-L. Electrochemical oxidation of the carbon support to synthesize $\mathrm{Pt}(\mathrm{Cu})$ and $\mathrm{Pt}-\mathrm{Ru}(\mathrm{Cu})$ core-shell electrocatalysts for low-temperature fuel cells. Catalysts 2015, 5, 815-837.

10. Qin, H.; Qian, X.; Meng, T.; Lin, Y.; Ma, Z. Pt/MO $/ \mathrm{SiO}_{2}, \mathrm{Pt} / \mathrm{MO}_{x} / \mathrm{TiO}_{2}$, and $\mathrm{Pt} / \mathrm{MO}_{x} / \mathrm{Al}_{2} \mathrm{O}_{3}$ catalysts for CO oxidation. Catalysts 2015, 5, 606-633.

11. Kuo, C.W.; Chen, B.K.; Tseng, Y.H.; Hsieh, T.H.; Ho, K.S.; Wu, T.Y.; Chen, H.R. A comparative study of poly(acrylic acid) and poly(styrenesulfonic acid) doped into polyaniline as platinum catalyst support for methanol electro-oxidation. J. Taiwan Inst. Chem. Eng. 2012, 43, 798-805. 
12. Habibi, B.; Pournaghi-Azar, M.H.; Abdolmohammad-Zadeh, H.; Razmi, H. Electrocatalytic oxidation of methanol on mono and bimetallic composite films: Pt and Pt-M ( $\mathrm{M}=\mathrm{Ru}$, Ir and Sn) nano-particles in poly(o-aminophenol). Int. J. Hydrogen Energy 2009, 34, 2880-2892.

13. Kuo, C.W.; Tsai, C.J.; Chen, W.P.; Chen, P.R.; Wu, T.Y.; Tseng, C.G. Nano-composite based on platinum particles and modified polyaniline for methanol, formic acid, and ethanol oxidation. J. Chin. Chem. Soc. 2014, 61, 819-826.

14. Sun, C.L.; Su, J.S.; Tang, J.H.; Lin, M.C.; Wu, J.J.; Pu, N.W.; Shi, G.N.; Ger, M.D. Investigation of the adsorption of size-selected Pt colloidal nanoparticles on high-surface-area graphene powders for methanol oxidation reaction. J. Taiwan Inst. Chem. Eng. 2014, 45, 1025-1030.

15. Maiyalagan, T.; Mahendiran, C.; Chaitanya, K.; Tyagi, R.; Nawaz Khan, F. Electro-catalytic performance of Pt-supported poly (o-phenylenediamine) microrods for methanol oxidation reaction. Res. Chem. Intermed. 2012, 38, 383-391.

16. Maiyalagan, T.; Dong, X.; Chen, P.; Wang, X. Electrodeposited Pt on three-dimensional interconnected graphene as a free-standing electrode for fuel cell application. J. Mater. Chem. 2012, 22, 5286-5290.

17. Maiyalagan, T.; Viswanathan, B. Synthesis, characterization and electrocatalytic activity of Pt supported on poly(3,4-ethylenedioxythiophene)- $\mathrm{V}_{2} \mathrm{O}_{5}$ nanocomposites electrodes for methanol oxidation. Mater. Chem. Phys. 2010, 121, 165-171.

18. Yang, C.C.; Wu, T.Y.; Chen, H.R.; Hsieh, T.H.; Ho, K.S.; Kuo, C.W. Platinum particles embedded into nanowires of polyaniline doped with poly(acrylic acid-co-maleic acid) as electrocatalyst for methanol oxidation. Int. J. Electrochem. Sci. 2011, 6, 1642-1654.

19. Selvaraj, V.; Alagar, M.; Hamerton, I. Electrocatalytic properties of monometallic and bimetallic nanoparticles-incorporated polypyrrole films for electro-oxidation of methanol. J. Power Sources 2006, 160, 940-948.

20. Fernandez-Blanco, C.; Ibanez, D.; Colina, A.; Ruiz, V.; Heras, A. Spectroelectrochemical study of the electrosynthesis of Pt nanoparticles/poly(3,4-(ethylenedioxythiophene) composite. Electrochim. Acta 2014, 145, 139-147.

21. Wu, T.Y.; Tsai, C.J.; Tseng, L.Y.; Chen, S.J.; Hsieh, T.H.; Kuo, C.W. Nanocomposite of platinum particles embedded into nanosheets of polycarbazole for methanol oxidation. J. Chin. Chem. Soc. 2014, 61, 860-866.

22. Nagashree, K.L.; Raviraj, N.H.; Ahmed, M.F. Carbon paste electrodes modified by Pt and Pt-Ni microparticles dispersed in polyindole film for electrocatalytic oxidation of methanol. Electrochim. Acta 2010, 55, 2629-2635.

23. Wu, T.Y.; Chen, Y. Synthesis and optical and electrochemical properties of novel copolymers containing alternate 2,3-quinoxaline and hole-transporting units. J. Polym. Sci. A 2002, 40, 4570-4580.

24. Kuo, C.W.; Hsieh, T.H.; Hsieh, C.K.; Liao, J.W.; Wu, T.Y. Electrosynthesis and characterization of four electrochromic polymers based on carbazole and indole-6-carboxylic acid and their applications in high-contrast electrochromic devices. J. Electrochem. Soc. 2014, 161, D782-D790. 
25. Mikkelsen, K.; Cassidy, B.; Hofstetter, N.; Bergquist, L.; Taylor, A.; Rider, D.A. Block copolymer template synthesis of core-shell PtAu bimetallic nanocatalysts for the methanol oxidation reaction. Chem. Mater. 2014, 26, 6928-6940.

26. Kham, K.; Sadki, S.; Chevrot, C. Oxidative electropolymerizations of carbazole derivatives in the presence of bithiophene. Synth. Met. 2004, 145, 135-140.

27. Gaupp, C.L.; Reynolds, J.R. Multichromic copolymers based on 3,6-bis(2-(3,4-ethylenedioxythiophene))- $N$-alkylcarbazole derivatives. Macromolecules 2003, 36, 6305-6315.

28. Nie, T.; Leng, J.; Bai, L.; Lu, L.; Xu, J.; Zhang, K. Synthesis and characterization of benzene sulfonate derivatives doped poly(3,4-ethylenedioxythiophene) films and their application in electrocatalysis. Synth. Met. 2014, 189, 161-172.

29. Kuo, C.W.; Sivakumar, C.; Wen, T.C. Nanoparticles of $\mathrm{Pt} / \mathrm{H}_{x} \mathrm{MoO}_{3}$ electrodeposited in poly(3,4-ethylenedioxythiophene)-poly(styrene sulfonic acid) as the electrocatalyst for methanol oxidation. J. Power Sources 2008, 185, 807-814.

30. Radmilovic, V.; Gasteiger, H.A.; Ross, P.N. Structure and chemical composition of a supported Pt-Ru electrocatalyst for methanol oxidation. J. Catal. 1995, 154, 98-106.

31. Qiu, L.H.; Liu, B.Q.; Peng, Y.J.; Yan, F. Fabrication of ionic liquid-functionalized polypyrrole nanotubes decorated with platinum nanoparticles and their electrocatalytic oxidation of methanol. Chem. Commun. 2011, 47, 2934-2936.

32. Kuo, C.W.; Chen, S.J.; Chen, P.R.; Wu, T.Y.; Tsai, W.T.; Tseng, C.G. Doping process effect of polyaniline doped with poly(styrenesulfonic acid) supported platinum for methanol oxidation. J. Taiwan Inst. Chem. Eng. 2013, 44, 497-504.

33. Niu, L.; Li, Q.; Wei, F.; Wu, S.; Liu, P.; Cao, X. Electrocatalytic behavior of Pt-modified polyaniline electrode for methanol oxidation: Effect of $\mathrm{Pt}$ deposition modes. J. Electroanal. Chem. 2005, 578, 331-337.

34. Raoof, J.B.; Ojani, R.; Hosseini, S.R. Electrocatalytic oxidation of methanol onto platinum particles decorated nanostructured poly(1,5-diaminonaphthalene) film. J. Solid State Electrochem. 2012, 16, 2699-2708.

35. Maiyalagan, T. Electrochemical synthesis, characterization and electro-oxidation of methanol on platinum nanoparticles supported poly(o-phenylenediamine) nanotubes. J. Power Sources 2008, 179, 443-450.

(C) 2015 by the authors; licensee MDPI, Basel, Switzerland. This article is an open access article distributed under the terms and conditions of the Creative Commons Attribution license (http://creativecommons.org/licenses/by/4.0/). 